\title{
Customer Satisfaction and Customer Loyalty in E-Banking in India: The Intricacies of Relationship
}

\author{
Ms. Navneet Kaur ${ }^{1}$ and Prof. (Ms) Ravi Kiran ${ }^{2}$ \\ ${ }^{I}$ Research Scholar, School of Behavioral Sciences and Business Studies \\ Thapar University, Patiala, Punjab,India-147004 \\ ${ }^{2}$ Professor \& Head, School of Behavioral Sciences and Business Studies \\ Thapar University, Patiala, Punjab,India-147004
}

\begin{abstract}
This study has been focused on finding the key determinants of customer loyalty and customer satisfaction in e-banking. The key factors of Customer loyalty are: customer retention; Security and Virtual Banking; and Technology invasion. Customer Retention emerges as an important factor influencing customer Loyalty with highest Eigen value and it explains maximum variation. This is followed by Security and Virtual Banking; and Technology invasion. Customer satisfaction is comprised of ten items. The study moves further to determine the relationship between the two. Customer Satisfaction is the dependent variable. Customer loyalty is associated positively with Confidence, Technology Adoption, Technical Expertise of staff, Personal Services, Account information, Channel Activity and Ease of Use from the construct of customer satisfaction. The model explains 85.8 percent of variation. Thus, a satisfied online customer can be retained by enhancing customer satisfaction.
\end{abstract}

Keywords: Technology Adoption, Personal Services, Ease of Use, Technology Invasion

\section{Introduction}

Are Consumers in India like other developed countries embracing e-banking with complete vigour and zeal? This question demands a thorough research analysis before it can be answered. Access to one's accounts at anytime and from any location via the World Wide Web is a convenience unknown a short time ago. Thus, a bank's electronic presence transforms from 'brochure-ware' status to 'Internet banking' status once the bank goes through a technology integration effort to enable the customers to access information the way they want.

With little difference in levels of technology among major banks, relationship building has assumed significance. However, Relationship Banking is not a new thing in banking, especially in India. Most successful managers in Public Sector Banks have thrived on the close liaison they had with their clients. A Trusted Bank Manager was almost a family member. However, the days of customer dependence on one organization for all his needs have undergone a sea change. Most Customers would prefer to choose and pick the best available alternative. The days of a committed customer are declining. Moreover the customers are now well educated and aware of the alternatives in the market. The job of banking staff becomes all the more challenging in today's competitive scenario. A Relationship based on mutual trust and respect will ensure that both the customer and more particularly, the bankers are benefited.

In order to reap the benefits of having retained customers and gaining competitive advantage online, banks need to develop a thorough understanding of the antecedents of retaining customers on the World Wide Web, such as technology factors or personal banking characteristics. In order to investigate the importance of eretention, the identification of variables influencing repeat purchasing behavior and word-of-mouth recommendation is a crucial area of research. This holds especially true for financial sector especially banks which already depend heavily on their reputations and long-lasting relationships in the offline world. The widespread adoption of online banking services calls for research investigating those factors which are responsible for retaining customers and keeping them satisfied.

This will help banks in the areas in which they can improve. Hindrances, such as waiting for information, losing a page, having to fill out forms more than once, or needing to enter the same information in multiple places, can prompt people to switch banks and demand attention to provide an insight into baking satisfaction and retention of customers. Customers expect e-banking applications to make managing their financial dealings easier, comfortable and secure.

More and more banks are now offering e-banking facilities, to target prospective customers, i.e. to convert offline users to being e- users. The new customer sign-up process may have bottlenecks that causing prospects to drop out. After sign-up, customers may not be aware of other bank products, which limits crossselling opportunities. And if customers do sign up for other financial products, the set-up process may seem too complex, leading them to visit a branch office instead, possibly a competitor's. And last but not the least, frequently-used products such as checking accounts or stock brokerage services are commoditized. 
Based on the above discussion, it can be said that bank's customer loyalty online and maintaining satisfaction of the customers all the time can be considered a quite new phenomenon that has not yet received much focus. So this study will have practical value, as the findings will be used by banks as guidelines of how to work with customers in the future. Additionally, it has academic value since it can contribute to the literature about online customers' retention and hence maintaining customers' satisfaction in e-banking and their retention.

\section{Theoretical Framework}

This research focuses on Customer satisfaction and Customer loyalty of E-Banking. Thus it is essential to review literature on these two key areas.

\subsection{Customer Satisfaction}

Customer satisfaction is stated to be one of the most important keystones when creating customer loyalty, especially in the bank sector as even discussed in [Ribbink, Van Riel, Liljander and Streukens (2004), Leverin and Liljander (2006) and Methlie and Nysveen (1999)]. Customer satisfaction is defined as 'an overall evaluation based on the total purchase and consumption experience focused on the perceived product or service performance compared with pre-purchase expectations over time [Sharma, N. and Patterson, (2000) and Beerli, Martin, and Quintana, (2004)]

To measure overall satisfaction of consumer, the construct has ten questions covering the customer services offered by the banks. These are:

i. Personal Services: Consumers appreciate the personal service they receive at their branch, but are such interactions slowly declining as the numbers of online, ATM and mobile banking transactions increase. This needs to be analysed (Jones, Mothersbaugh and Beatty (2000)].

ii. Confidence: Successful banks have to ensure customer confidence. They don't have to push customers out of the branch, but rather have to provide tools to make it easier to conduct their banking business when and where it is convenient for them. [Colgate and Lang (2001)]

iii. Problem Resolution and Customer Care: Many banks make great strides by listening to what their customers are asking for. They try to reduce the number of problems customers encounter and, more importantly, improving satisfaction. Here customer may not mind paying a little extra for such service.

iv. Fees: Elimination of Free checks: During the past several years, many banks have eliminated free checking and implemented new fees, which has often negatively impacted overall satisfaction.

v. Facilities: Customer satisfaction may improve with provision of latest facilities by banks.

vi. Account information: Providing transaction details and statement regularly is another step to enhance satisfaction.

vii. Ease of Use: Measures accessibility and quality of service from delivery channels. The advent of more sophisticated technologies have increased customer convenience in conducting transactions, customers have become even more demanding, as they expect better quality at lower costs. [4]

viii. Technology Adoption: In the banking sector it is necessary to increase adoption of technology to better meet customer requirements, improve efficiencies, reduce costs and ensure customer delight and it was the private sector and foreign banks which established the technological revolution in Indian banking and considering the fact that in the new economy, mind share leads to market share and mind share is influenced not only by the promotions and advertisements but more importantly on favorable customer perception which in turn is based on satisfaction with regard to products, services and interaction. [Eriksson, Kerem \& Nilsson (2008); Sayar and Wolfe (2007)]

ix. Channel Activity: Online banking presents banks with the opportunity to deepen relationships with customers to enhance channel activity. The service quality of alternate channels will be important for engaging this customer category in the future. Branch based banking is simply too time consuming for young professionals, who would prefer a more expedient way to fulfill their banking transactions.

x. Technical Expertise of staff: Relationship of banking staff is important for satisfaction of Banking. In ebanking Technical Expertise of staff is very important to build long lasting relation with customers.

\section{2: Customer Loyalty}

The terms 'customer retention' and 'customer loyalty' are often used interchangeably in literature. Customer retention has been conceptualized as a dimension of a customer loyalty construct as shown by [Boulding, Kalbra, Staeling, and Zeithaml (1993) \& Zeithaml, Berry, and Parasuraman(1996)]. Customer retention and customer loyalty are not surrogate for each other because the two terms can refer to different things. Therefore it is suggested that the conceptualization of customer loyalty and retention needs further clarification. [Thorsten (2000)] 
Several studies have been made on which determinants retain bank customers [Beerli, Martin, and Quintana (2004)]. Research shows that customer satisfaction and switching costs are two main determinants, satisfaction the strongest one. Methlie and Nysveen (1999) has demonstrated that customer satisfaction and brand reputation are the most important determinants. Lewis\& Soureli (2006) has stated that customer satisfaction, perceived service quality, service attributes, corporate image, perceived value, switching costs, interpersonal relationships with bank employees commitment-attachment, trust, customer characteristics and organizations efforts to make relationship all are precedents of customer loyalty. Abratt and Russel (1999) opined that customers with personal relationships are loyal to their bank. Through interaction between all these concepts, customer loyalty is created.

The study has been taken with the following major objectives:

1. To identify the key factors influencing Customer Loyalty

2. To find out the relation between customer satisfaction and customer loyalty.

The hypotheses of the study are:

$\mathbf{H}_{\mathbf{1}}$ : There is a significant difference in customer satisfaction and the three categories of banks, viz. public sector banks, private sector banks and foreign banks.

$\mathbf{H}_{2}$ : Customer retention is an important factor of Customer loyalty.

$\mathbf{H}_{3}$ : Technology is an important factor influencing Customer loyalty in E-Banking.

$\mathbf{H}_{4}$ : Customer loyalty may be an important predictor of Customer satisfaction.

\subsection{Data Collection}

\section{Research Methodology}

This research study is based on random sampling and self-structured questionnaire has been be used to gather data from the respondents in and around New Delhi. In all 800 questionnaire were distributed, 415 were received and four hundred questionnaire complete in all aspects have been taken for the study. The response rate has been 51.87 percent. The questionnaire has been validated by academicians and banks managers. The suggestions given by them have been incorporated in the questionnaire.

For the purpose of conducting this study, primary data has been used. A well-structured questionnaire has been designed so as to take responses from customers who are using e-banking services and from prospective customers of e-banking also. The questionnaire is based on 5 point Likert Scale. The sample size is 400. The study has been conducted in Delhi and NCR. The reliability score of questionnaire has been presented in table I. The overall reliability has been 0.954 .

Table I: Reliability Statistics

\begin{tabular}{|l|l|l|l|}
\hline S No & Items & Item Name & Cronbach Alpha \\
\hline 1 & 14 & E- Banking Features & 0.875 \\
\hline 2 & 10 & Customer Satisfaction & 0.754 \\
\hline 3 & 18 & Customer loyalty & 0.945 \\
\hline 4 & 42 & Total & 0.954 \\
\hline
\end{tabular}

\section{Empirical Analysis}

The data so gathered has subjected to statistical analysis using SPSS software. The study uses descriptive statistics for explain attitude of users of e-banking. Factor analysis and multiple regression techniques have been used for testing the hypothesis.

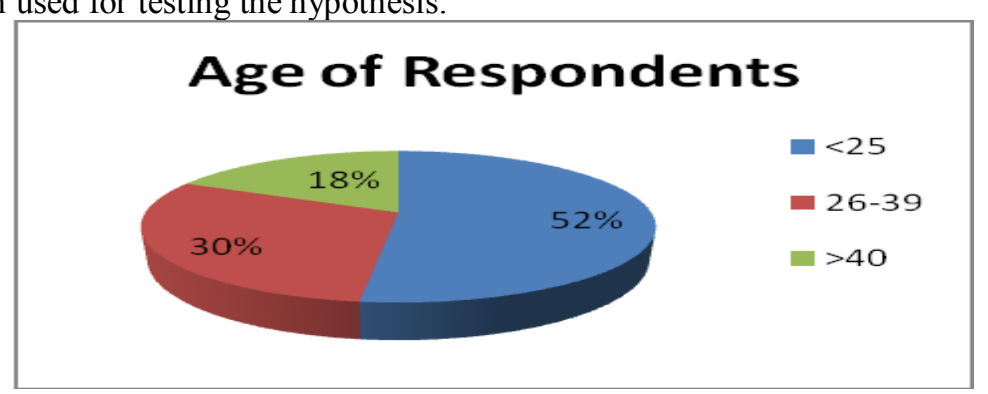

Figure 1: Age of Respondents

\subsection{Demographic and Banking Profile:}

Majority of respondents were less than thirty, followed by $30-45$. There were $18 \%$ respondents who were more than 45. Although equal number of forms was submitted to all categories, the response rate from the last category was lower than the other two categories. 


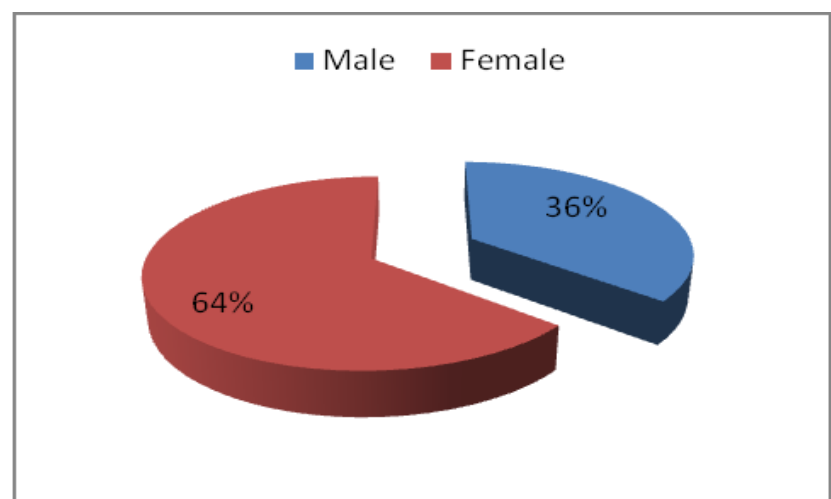

Figure 2: Gender-wise analysis

Gender-wise Analysis as depicted through figure 2 that 64 percent respondents are males and 36 percent are females. The sample is dominated by male respondents.

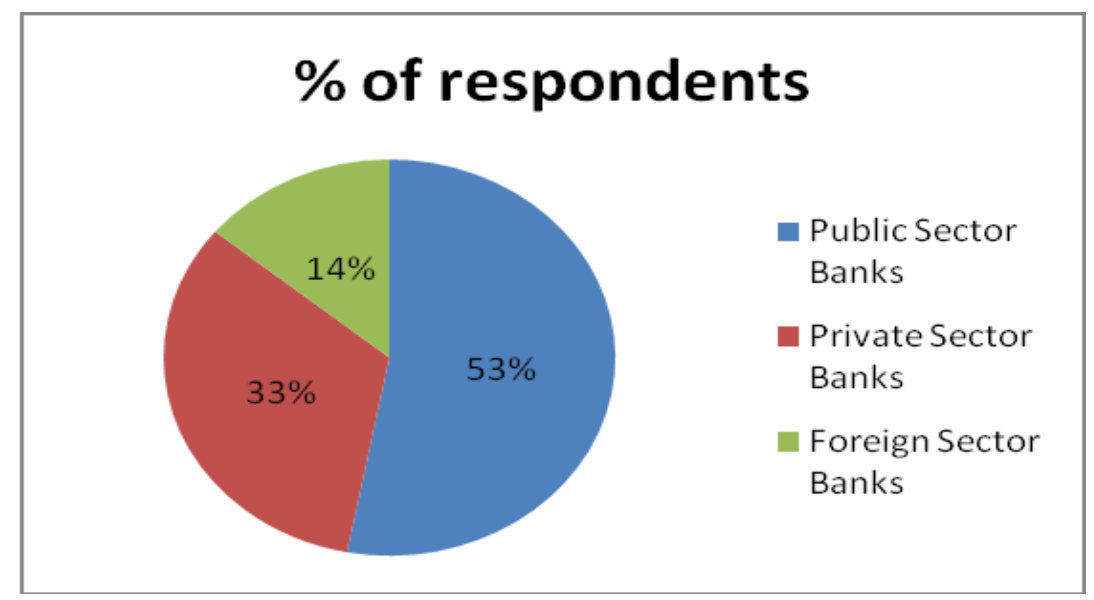

Figure 3: Category of Banks

Category of Banks as shown through figure 3 highlights that respondents from Public Sector Banks constitute the majority. Respondents from Foreign banks constitute mere 14 percent.

\subsection{Customer satisfaction and Categories of Banks}

ANOVA results as depicted through table II highlight that there is a significant difference in the customer satisfaction in all three categories of banks viz. Public sector, private sector and foreign banks. Thus the hypothesis $\mathrm{H}_{1}$ : There is a significant difference in customer satisfaction and the three categories of banks, viz. public sector banks, private sector banks and foreign banks has been accepted as $p$ is significant for all ten sub factors of customer satisfaction.

Table II: ANOVA Results for Customer satisfaction and Categories of Banks

\begin{tabular}{|c|c|c|c|c|c|c|}
\hline & & Sum of Squares & Df & Mean Square & $\mathrm{F}$ & Sig. \\
\hline \multirow{3}{*}{$\mathrm{CS} 1$} & Between. Groups & 22469 & 2 & 11234 & 34819 & .000 \\
\hline & Within Groups & 128091 & 397 & 0323 & & \\
\hline & Total & 150560 & 399 & & & \\
\hline & Between. Groups & 16939 & 2 & 8469 & 27537 & .000 \\
\hline \multirow[t]{3}{*}{$\mathrm{CS} 2$} & Within Groups & 122101 & 397 & 0308 & & \\
\hline & Total & 139040 & 399 & & & \\
\hline & Between. Groups & 17911 & 2 & 8956 & 19629 & .000 \\
\hline \multirow[t]{3}{*}{$\mathrm{CS} 3$} & Within Groups & 181129 & 397 & 0456 & & \\
\hline & Total & 199040 & 399 & & & \\
\hline & Between. Groups & 51978 & 2 & 25989 & 23917 & .000 \\
\hline \multirow[t]{3}{*}{$\mathrm{CS} 4$} & Within Groups & 431382 & 397 & 1087 & & \\
\hline & Total & 483360 & 399 & & & \\
\hline & Between. Groups & 4236 & 2 & 2118 & 30282 & .000 \\
\hline \multirow[t]{2}{*}{ CS5 } & Within Groups & 27764 & 397 & 0070 & & \\
\hline & Total & 32000 & 399 & & & \\
\hline
\end{tabular}




\begin{tabular}{|c|c|c|c|c|c|c|}
\hline \multirow{4}{*}{ CS6 } & Between. Groups & 25752 & 2 & 12876 & \multirow[t]{2}{*}{24147} & \multirow[t]{2}{*}{.000} \\
\hline & Within Groups & 211688 & 397 & 0533 & & \\
\hline & Total & 237440 & 399 & & & \\
\hline & Between. Groups & 0812 & 2 & 0406 & 3614 & 0028 \\
\hline \multirow{3}{*}{ CS7 } & Within Groups & 44628 & 397 & 0112 & & \\
\hline & Total & 45440 & 399 & & & \\
\hline & Between. Groups & 21805 & 2 & 10902 & 10454 & 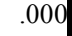 \\
\hline \multirow[t]{3}{*}{ CS8 } & Within Groups & 414035 & 397 & 1043 & & \\
\hline & Total & 435840 & 399 & & & \\
\hline & Between. Groups & 35066 & 2 & 17533 & 15555 & 00 \\
\hline \multirow[t]{3}{*}{ CS9 } & Within Groups & 447494 & 397 & 1127 & & \\
\hline & Total & 482560 & 399 & & & \\
\hline & Between. Groups & 4552 & 2 & 2276 & 8409 & \\
\hline \multirow[t]{2}{*}{$\mathrm{CS} 10$} & Within Groups & 107448 & 397 & 0271 & & \\
\hline & Total & 112000 & 399 & & & \\
\hline
\end{tabular}

Thus, on the basis of ANOVA all ten factors have been included in Consumer satisfaction for further analysis to determine relation between consumer satisfaction and Customer loyalty. Next aspect is to extract factors for online customer loyalty through factor analysis.

\subsection{Customer Loyalty}

\begin{tabular}{|c|c|c|c|c|c|}
\hline \multicolumn{6}{|c|}{ Table III: Factors influencing Customer loyalty } \\
\hline Factor Name & Eigen Value & $\begin{array}{l}\% \text { of Variance } \\
\text { Explained }\end{array}$ & & Item Name & Item Loading \\
\hline \multirow{9}{*}{ Customer Retention } & \multirow{9}{*}{7.933} & \multirow{9}{*}{46.666} & i. & Satisfaction regarding e-banking & 0.878 \\
\hline & & & ii. & Accuracy of reporting transactions & 0.821 \\
\hline & & & iii. & Inconvenience in changing bank & 0.764 \\
\hline & & & iv. & Good relationship with staff & 0.742 \\
\hline & & & $\mathrm{v}$. & $\begin{array}{l}\text { Providing updated information regarding rewards and } \\
\text { schemes }\end{array}$ & 0.652 \\
\hline & & & vi. & Ability to meet consumer's changing needs & 0.803 \\
\hline & & & vii. & $\begin{array}{l}\text { Comfort of electronic banking channels to carryout } \\
\text { banking transactions than physically going to branch }\end{array}$ & 0.813 \\
\hline & & & viii. & $\begin{array}{l}\text { E-Banking has reduced the 'Gap' between the bank and } \\
\text { the client" }\end{array}$ & 0.909 \\
\hline & & & ix. & $\begin{array}{l}\text { Preference to choose the Internet banking service of } \\
\text { prime bank. }\end{array}$ & 0.895 \\
\hline \multirow{4}{*}{$\begin{array}{c}\text { Security and } \\
\text { Virtual Banking }\end{array}$} & \multirow{4}{*}{3.382} & \multirow{4}{*}{19.897} & i. & Safety measures of banks & 0.855 \\
\hline & & & ii. & $\begin{array}{l}\text { Security of availability and managing of financial } \\
\text { information over internet }\end{array}$ & 0.685 \\
\hline & & & iii. & $\begin{array}{l}\text { Willingness to pay a higher price for using secure } \\
\text { Internet banking service }\end{array}$ & 0.768 \\
\hline & & & iv. & E-Banking is replacing Physical Branches & 0.680 \\
\hline \multirow{5}{*}{ Technology Invasion } & \multirow{5}{*}{2.759} & \multirow{5}{*}{16.231} & $\mathrm{i}$. & Technical expertise of staff & 0.730 \\
\hline & & & & $\begin{array}{l}\text { Invasion of technology in banks has improved the service } \\
\text { level of banks }\end{array}$ & 0.876 \\
\hline & & & iii. & Implementation of latest technology by the prime bank & 0.776 \\
\hline & & & iv. & $24 * 7-$ telephonic support & 0.813 \\
\hline & & & & $\begin{array}{l}\text { Necessity of Human contact between bank and the } \\
\text { customer }\end{array}$ & 0.604 \\
\hline
\end{tabular}

Results as shown in table III, Customer loyalty factor has highest Eigen value and is explaining 46.666 $\%$ of variation. In this factor, higher ratings have been given to: i] E-Banking has reduced the 'Gap' between the bank and the client; ii] Satisfaction regarding e- banking and I- Banking; iii] Preference to choose the Internet banking service of prime bank and iv] Safety measures of bank. Earlier literature supports that customers tend to stay loyal with their service providers if they have excellent relationship with its staff [Ennew and. Binks (1996); Abratt and Russel (1999)] . There is other evidence also available in literature which supports that customer retention has been conceptualized as a dimension of a customer loyalty construct [Zeithaml, Berry and Parasuraman (1996); Thorsten (2000). Thus Hypothesis $\mathrm{H}_{2}$ : Customer retention may be an important factor influencing Customer loyalty has been accepted. Respondents still feel that providing updated information regarding rewards and schemes; and Good relationship with staff have been rated lower. Thus there is scope for improving retention by focusing on these [Howcroft, Hamilton and Hewer (2002)].

Regarding second factor viz. Security and Virtual Banking there is still scope for improvement as the customers have rated only safety measures of banks with 0,855 . Other variables like security of availability and managing of financial information over internet is having lower ratings, so the banks have to put more focus on security aspects. Online consumers are increasingly concerned about security and privacy issues There is 
diverse literature supporting lack of security and trust as a major reason why consumers are still reluctant to conduct transactions online (Mukherjee and Nath, 2003; Luarn and Lin, 2005; Flavian et al., 2006). Shanmugam and Guru (2000) found that Internet banking was nearly absent in Malaysian banks due to lack of adequate legal framework and security concerns. Unnithan et al. (2001) in a comparative study on e- banking in Australia and India reported that in Australia Internet ready infrastructure as telecommunication, secure protocols, PC penetration and consumers' literacy is high compared to India. Thus the present study tried to look in to security issues concerning respondents of the sample.

Technology Invasion factor has lower Eigen value of 2.759. In this factor Invasion of technology has improved banking services has high loading of 0.876 , followed by $24 * 7$ - telephonic support having Eigen value of 0.813 . Thus, the third hypothesis, $\mathrm{H}_{3}$ : Technology may be an important factor influencing with Customer loyalty has been accepted though the value is slightly lower than other factors [Roboff and Charles( 1998)].

This is supported by earlier literature as according to Roboff and Charles (1998) consumers confidence in bank is strong, yet their confidence in the technology was weak. All these three factors explain 82.94 percentage of Variation.

Table IV: Relation between Customer Satisfaction and Customer Loyalty

\begin{tabular}{|c|c|c|c|c|c|c|c|c|c|c|}
\hline \multirow[t]{2}{*}{ Model } & \multirow[t]{2}{*}{$\mathrm{R}$} & \multirow[t]{2}{*}{ R Square } & \multirow[t]{2}{*}{ Adjusted R Square } & \multirow{2}{*}{$\begin{array}{c}\text { Std. Error of the } \\
\text { Estimate }\end{array}$} & \multicolumn{5}{|c|}{ Change Statistics } & \multirow[t]{2}{*}{ Durbin-Watson } \\
\hline & & & & & $\begin{array}{l}\text { R Square } \\
\text { Change }\end{array}$ & F Change & $\mathrm{df1}$ & $\mathrm{df} 2$ & Sig. F Change & \\
\hline 1 & $0.814^{\mathrm{a}}$ & 0.663 & 0.662 & 0.22347 & 0.663 & 7810.282 & 1 & 398 & .000 & \\
\hline 2 & $0.839^{\mathrm{b}}$ & 0.703 & 0.702 & 0.20986 & 0.041 & 540.285 & 1 & 397 & .000 & \\
\hline 3 & $0.868^{\mathrm{d}}$ & 0.754 & 0.752 & 0.19144 & 0.050 & 810.086 & 1 & 396 & .000 & \\
\hline 4 & $0.899^{\mathrm{d}}$ & 0.809 & 0.807 & 0.16875 & 0.055 & 1140.635 & 1 & 395 & .000 & \\
\hline 5 & $0.908^{\mathrm{e}}$ & 0.824 & 0.822 & 0.16229 & 0.015 & 330.053 & 1 & 394 & .000 & \\
\hline 6 & $0.923^{\mathrm{f}}$ & 0.853 & 0.850 & 0.14857 & 0.029 & 770.132 & 1 & 393 & .000 & \\
\hline 7 & $0.928^{\mathrm{g}}$ & 0.860 & 0.858 & 0.14487 & 0.008 & 210.362 & 1 & 392 & .000 & 2.071 \\
\hline
\end{tabular}

a. Predictors: [Constant], Confidence

b. Predictors: [Constant], Confidence, Technology Adoption

c. Predictors: [Constant], Confidence, Technology Adoption, Technical Expertise of staff

d. Predictors: [Constant], Confidence, Technology Adoption, Technical Expertise of staff, Personal Services

e. Predictors: [Constant], Confidence, Technology Adoption, Technical Expertise of staff, Personal Services, Account information

f. Predictors: [Constant], Confidence, Technology Adoption, Technical Expertise of staff, Personal Services, Account information, Channel Activity

g. Predictors: [Constant], Confidence, Technology Adoption, Technical Expertise of staff, Personal Services, Account information, Channel Activity, Ease of Use

Dependent Variable: Customer Loyalty

\begin{tabular}{|c|c|c|c|c|c|}
\hline \multicolumn{6}{|c|}{$\mathrm{ANOVA}^{\mathrm{a}}$} \\
\hline Model & Sum of Squares & $\mathrm{df}$ & Mean Square & $\mathrm{F}$ & Sig. \\
\hline Reg. & 50.663 & 7 & 7.238 & 344.871 & $.000^{\mathrm{h}}$ \\
\hline Residual & 8.227 & 392 & .021 & & \\
\hline Total & 58.890 & 399 & & & \\
\hline \multirow{2}{*}{ Model } & \multicolumn{2}{|c|}{ Unstandardized Coefficients } & Standardized Coefficients & $\mathrm{t}$ & Sig. \\
\hline & $\mathrm{B}$ & Std Error & Beta & & \\
\hline [Constant] & 1.005 & 0.064 & & 15.707 & .000 \\
\hline Confidence & 0.549 & 0.016 & 0.840 & 34.143 & .000 \\
\hline Technology Adoption & 0.063 & 0.012 & 0.181 & 5.426 & .000 \\
\hline Technical Expertise of staff & 0.486 & 0.024 & 0.747 & 20.264 & .000 \\
\hline Personal Services & 0.390 & 0.024 & 0.547 & 16.475 & .000 \\
\hline Account information & 0.226 & 0.022 & 0.628 & 10.368 & .000 \\
\hline Channel Activity & -0.187 & 0.019 & -0.596 & -9.998 & .000 \\
\hline Ease of Use & 0.062 & 0.014 & 0.195 & 4.622 & .000 \\
\hline
\end{tabular}

Results of Regression (table IV) highlight that the model has chosen Confidence, Technology Adoption, Technical Expertise of staff, Personal Services, Account information, Channel Activity and Ease of Use from the construct of customer satisfaction. These seven factors explain 85.8 percent of variation. All variables except Channel Activity are positively related with Customer loyalty.

With the introduction of these seven factors Adjusted $\mathrm{R}^{2}$ improved from 0.662 to 0.858 . The results indicate that satisfaction has a significant positive $\mathrm{R}^{2} 0.858$ effect on customer loyalty in the context of Internet banking. The result confirmed that customer satisfaction has a positive impact on retention in the context of Internet banking. 


\section{Discussion And Conclusions}

As highlighted through the results, the key determinants of Customer Loyalty are: i] customer Retention; Security and Virtual Banking; and Technology invasion. From these three factors, Customer Retention emerges as an important factor influencing customer loyalty. Security and Virtual Banking; and Technology invasion also emerge as factors influencing customer loyalty. This has been corroborated by earlier studies [Boulding, Kalbra, Staeling, and Zeithaml (1993); Zeithaml, and Parasurama (1996)].

Customer satisfaction is comprised of ten items. From these the Regression model has chosen Confidence, Technology Adoption, Technical Expertise of staff, Personal Services, Account information, Channel Activity and Ease of Use from the constructs of customer satisfaction. These seven factors explain 85.8 percent of variation. The result confirmed that customer satisfaction has a positive impact on retention in the context of Internet banking. This study enriches the understanding of factors of customer loyalty and relation between customer satisfaction and customer loyalty with respect to online banking in India. Thus, banks should focus on providing customer satisfaction to online consumers for improved customer loyalty. According to regression results, the main hypothesis that Customer satisfaction is related with Customer loyalty is supported. This has been accepted by earlier researchers [Rust and Zahorik (1993); Croninand Taylo (1992); Patterson, Johnson, and Spreng (1997); Leverin, and Liljander [2006] ; Ndubisi [2007].

\section{References}

[1]. Abratt, R., Russel, J. (1999) Relationship marketing in private banking in South Africa, International Journal of Bank Marketing, 17 (1), 5-19.

[2]. Bauer, H. H., Hammerschmidt, M. and Falk, T. (2005). Measuring the quality of e-banking portals. International Journal of Bank Marketing, 23 (2), 153-175.

[3]. Beerli, A., Martin, J. D. and Quintana, A., (2004) A model of customer loyalty in the retail banking market, European Journal of Marketing, 38 (2), 253-275.

[4]. Boulding, K. D., Kalbra, A., Staeling, R., and Zeithaml, V. A. [1993] A Dynamic Process Model of Service Quality: From Expectations to Behavioral Intentions. Journal of Marketing Research, 30 (2), 7-27.

[5]. Colgate, M. and Lang, B. (2001) Switching Barriers in Consumer Market: An Investigation of the Financial Services Industry, Journal of Consumer Marketing, 18, (4), 332-347

[6]. Cronin, J. J. and Taylor, S. A. (1992) Measuring Service Quality: A Reexamination and Extension, Journal of Marketing, 56 (1), $55-68$.

[7]. Ennew, C.T., M.R. Binks. The Impact of Service Quality and Service Characteristics on Customer Retention: Small Business and their Banks in the UK, British Journal of Management, 7 1(1), 219-230.

[8]. Eriksson, K., Kerem, K., \& Nilsson, D. (2008) The adoption of commercial innovations in the former Central and Eastern European markets. The case of internet banking in Estonia, International Journal of Bank Marketing, 26, (3), 154-69.

[9]. Flavian, C., Guinaliu, M. and Torres, E. (2006) How bricks-and-mortar attributes affect online banking adoption, The International Journal of Bank Marketing, 24 (6), 406.

[10]. Howcroft, B., Hamilton, R. and Hewer, P. Consumer attitude and the usage and adoption of home-based banking in the United Kingdom, The International Journal of Bank Marketing, 20 (3), 111-21.

[11]. Jones, M. A., Mothersbaugh, D. L., and Beatty, S. E. (2000) Switching Barriers and Repurchase Intentions in Services, Journal of Retailing, 76 (2), 259-374.

[12]. Kotler, P., Armstrong, G. and Cunningham, P. G. Principles of Marketing, Prentice-Hall, Englewood Cliffs, NJ (2002).

[13]. Leverin, A., \& Liljander, V. (2006) Does relationship marketing improve customer relationship satisfaction and loyalty? International Journal of Bank Marketing 24(4), 232-251

[14]. Lewis, R., \& Soureli, M. (2006) The antecedents of consumer loyalty in retail banking, Journal of Vonsumer Behaviour, 5 (1), 15 31.

[15]. Luarn, P. and Lin, H.H. (2005) Toward an understanding of the behavioral intention to use mobile banking, Computers in Human Behavior, 21, 873-91.

[16]. Methlie, L.B., \& Nysveen, H. (1999). Loyalty of on-line bank customers. Journal of Information Technology, 14 (2),375-386

[17]. Mukherjee, A., and Nath, P. (2003) A model of trust in online relationship banking', International Journal of Bank Marketing, 21(1), 5-15.

[18]. Ndubisi, N. (2007) Relationship Marketing and Consumer Loyalty, Marketing Intelligence and Planning, 25 (1), 98-106.

[19]. Patterson, P. G., Johnson, L. W., and Spreng, R. A. (1997) Modeling the Determinants of Customer Satisfaction for Business-toBusiness Professional Services // Journal of the Academy of Marketing Science, 25 (1),4-17.

[20]. Ribbink, D., Van Riel, A., Liljander V., and Streukens, S. (2004) Comfort your Online Customer: Quality, Trust and Loyalty on the Internet, Managing Service Quality, 14 (6), 446-456.

[21]. Roboff, G. and Charles, C. (1998) Privacy of financial information in cyberspace: banks addressing what consumers want, Journal of Retail Banking Services, 20 (3), 51-56.

[22]. Rust, R. T. and Zahorik, A. J. (1993) Customer Satisfaction, Customer Retention, and Market Share, Journal of Retailing, 69 (2), 193-215.

[23]. Sayar, C. and Wolfe, S. (2007) Internet banking market performance: Turkey versus the UK. International Journal of Bank Marketing, 25 (3), 122-141.

[24]. Shanmugam, B. and Guru, K., (2000) E-banking developments in Malaysia: Prospect and Problems, Journal of International Banking Law. 15 (10), 250-256.

[25]. Sharma, N. and Patterson, P.G. (2000) Switching costs, alternative attractiveness and experience as moderators of relationship commitment in professional consumer services, International Journal of Service Industry Management, 11(5), 470-490.

[26]. Thorsten, Hennig-Thurau (2000) Relationship Quality and Customer Retention through Strategic Communication of Customer Skills, Journal of Marketing Management, 16 (3), 55-79. 
[27]. Unnithan, C. and Swatman, P. (2001) E-Banking Adaptation and Dot.Com Viability-A comparison of Australian and Indian Experiences in the Banking Sector, Proceedings of the 11th Annual BIT Conference 2001, Manchester Metropolitan University Business School, Manchester. https://dro.deakin.edu.au/eserv/DU:30013661/swatman-ebanking-2001.pdf

[28]. Zeithaml, V. A., Berry, L. L., and Parasuraman, A. (1996) The Behavioural Consequences of Service Quality, Journal of Marketing, 60 (4), 31-46. 